\title{
An Investigation of Corporate Social Investment (CSI) Programme's Contribution to the Brand Image of a Financial Institution in Alexandra, South Africa
}

Prof KC Moloi

\author{
Vaal University of Technology, Faculty of Human Sciences \\ Vanderbijlpark, 1900 \\ Email:conniem@vut.ac.za
}

\section{Ms Anna Oksiutycz-Munyawiri}

University of Johannesburg Aucklandpark, 2006, Johannesburg

Email:aoksiutycz@uj.ac.za

\section{Gildas Ndong}

Vaal University of Technology, Faculty of Human Sciences

Vanderbijlpark, 1900

Email:relationniste@hotmail.com

Doi:10.5901/mjss.2014.v5n4p282

Abstract

This article explores and explains Corporate Social Investment (CSI) and its contribution to the brand image of a financial institution in the area of Alexandra. The researchers used qualitative research study through focus groups with the communities of Alexandra and in-depth individual interviews with the management of the financial institution. The study sought to analyse and investigate the relationships between the communities and the management who employs corporate social investment in the area and its possible impact to the brand image of the organisation. Often seen as a township, Alexandra is described as a strategic neighbourhood for many corporations that have their business operations in that area. Because of this reason, some businesses such as the financial institution have been investing through their CSI activities but those have paid little attention to the communities in terms of taking into account their priority concerns even if the bulk of the institution's investment which the communities acknowledge and agree is part of the developmental agenda: education. Some of the findings are that the formulation and implementation of projects are done by the institution with the community centre with little consultation with the communities who are the intended beneficiaries of the projects and which affect the relationships between the communities and the organisation.

Keywords: Corporate social investment, brand image, resource dependency theory, measurable impact, Alexandra community

\section{Introduction}

This study investigates corporate social investment programme's contribution to the brand image of a financial institution in Alexandra. Corporate Social Investment (CSI), which refers to the projects that are external to the normal business activities of a company, is the wealth and sustainability companies create by investing in long-term projects with measurable impact on the communities they serve (William, Werther \& Chandler 2011:8). This is because business is no longer regarded as separate from society but part of it and therefore has the responsibility for contributing to social development in its neighbouring communities through CSI development programmes. Georges (2005:21) defines the community as groups existing actively within a geographical area and making corporations account for what they are doing. In the researcher's schema, organisations that are located within communities should take the opportunity to impact their lives through various CSI projects and programmes.

The study uses the CSI, resource dependency theory and the social exchange theory for its theoretical framework. The CSI theory was developed by Broom, Casey and Ritchey (2000) and Grunig and Huang (2000), who posit that the dominant public relations approach to studying corporate social investment comes from the resource dependency theory 
and exchange theory. The exchange theory as developed by Bender (2011:110) states that in order to grow, survive and achieve its goals an organisation needs resources. The CSI theoretical framework holds that voluntarily transactions which are part of the exchange theory result from "knowledge of domain similarity and leads to mutual benefits as well as to mutual goal achievement" (Broom, Casey \& Ritchey 2000:13). The researcher believes that the CSI framework is pertinent to this study because, when in regard to community relations and brand image one often believes that their interaction is about forging strategic relations of mutual benefit.

Previous studies on CSI contribution by Desatnik (2000:2) show how a company has gained long-term benefits and more visibility with regards to community loyalty and development, both as a result of its contribution. These studies are useful for providing existing literature relevant to the present one, but are silent on CSI's contribution in Alexandra. This gap provides that rationale for my study.At the heart of this business approach, namely CSI, are community relations, with which community members are considered as stakeholders with whom to establish bonds. James (2002:103) views the stakeholders as people who are affected by an organisational endeavour and can influence it, but who are not directly involved in doing the work. Extending this view, Dahlen, Lange and Smith (2010:221) assert that community relations go with having good relationships that are also important to brand longevity while embarking on the CSI cause. Soderberg (1986:1) emphasises the need for companies to take an active interest in community problems, encouraging community education and sponsoring youth activities in dealing with community relations.

Research by Rashid and Ibrahim (2002:12) shows that those companies that are keen on enhancing their brands should strengthen community relations with those that surround their businesses. Healey (2008:9) provides a link between CSI and branding by indicating that corporations create brands as a way of seeking recognition from the communities and increasing sales outside their immediate place of production. He writes that brand image involves such components as accountability, and community relationships which are of interest to an organisation toward their communities, including public affairs and stakeholder relationships.

Currently, the corporate sphere has turned towards the broader societal issues, in which considerations such as dialogue with communities, image of the company and the brand have come into play in earning legitimacy among stakeholders (Sandra 1996:44). By advancing social and environmental needs of the society and investing in the wellbeing of the communities in which they operate, companies engage in CSI. The researcher believes that while corporations build wealth for shareholders they should also consider the socio-economic need of the stakeholders they serve. In order to achieve this, the stakeholder analysis should be regularly conducted to assess the kinds and degrees of obligation that corporations have to each stakeholder, including the community. The purpose of this study is to understand the CSI programme's contribution to the brand image of the selected financial institution in Alexandra, and how its corporate social investment programme's contribution to the brand image can enhance the lives of the community members.

\section{Rationale and Motivation for the Study}

Corporate social investment programmes make a significant contribution to development in South Africa, however, the needs are much greater. Therefore it is critical that the corporate resources are allocated strategically to achieve sustainable results for the targeted communities. Skinner and von Essen (2008: 241) assert that less than 45\% of CSI programmes have well established guidelines for the best practice and only around $50 \%$ of the programmes engage in stakeholder consultation and regular monitoring and measurement, therefore it is important to research the community perspective on the Corporate Social Responsibility (CSR) programme of the financial institution in Alexandra. At the same time the literature indicates a positive relationship between CSI and brand image of the company (Hinson \& Ndhlovu 2011:334, Polonski \& Jevons 2009:327), therefore it is important to research these relationship in the case of the studied organisation.

The South African financial institution at the centre of the study, is a corporate giver, which within the framework of its community relations programme, invests in various projects ranging from the provision of recreational centres, libraries and social service facilities to support the vulnerable (the elderly, women and children) across the country, particularly Alexandra Township. The researcher is not clear to what extent these projects fulfil the needs and expectations of the community in Alexandra or how the interventions strengthen corporate social investment's contribution to the brand image of the institution. This gap has prompted the researcher to look at the CSI programme's contribution to the brand image of the financial institution under investigation in order to receive better clarity on its brand success. The current projects, which started in 2010 , are run by the community centre whose role is to help the communities to gather for group activities, such as Islamic community centres (Feth) or Christian community centres. 


\section{Problem Statement}

A discussion with some community members in Alexandra in 2009 revealed that the community members were concerned that the financial institution selected for this study had not engaged them in developing its CSI programmes. Despite the presence of the researched financial institution in Alexandra, the community members in that area were of the opinion that there is no follow-up regarding its CSI programmes. According to the informants, the organisation's investment actions (social service facilities and support to the vulnerable) that are aimed at enhancing and improving the community's well-being do not reflect the its expectations.

\section{Research Questions}

In line with the problem statement, and in order to focus the purpose of the study, the research questions are:

- What is the corporate social investment's contribution to the brand image of the financial institution in Alexandra?

- How do the Alexandra community members perceive the relationships between the financial institution and the community?

- How can the community relations between the financial institution and the Alexandra community be improved?

\section{Aims of the Study}

In line with the research questions stated above, the aims of this study are to:

- Understand the nature of corporate social investment programme's contribution to the brand image of the financial institution in Alexandra?

- Explore how the Alexandra community members perceive the relationships between the financial institution and the community.

- Suggest strategies to improve community relations between the financial institution and the Alexandra community members.

\section{Theoretical Foundatons of CSI}

Some theorists tend to position public relations as an occupation that seeks to establish true dialogue between an organisation and its stakeholders (L'Etang 2008:24). This is how CSI programs are connected to the core values of the firm that is a relationship with the communities which reflect where community problems or needs by relevant stakeholder groups are taken into consideration. In line with this, Broom, Casey and Ritchey (2000:12) and Grunig and Huang (2000:35) consider the exchange theory and resource dependency theory as the ideal approach to studying CSI.

\subsection{Social exchange theory}

Social exchange theory assumes that social behaviour is the result of an exchange process that places emphasis on the economic view of human relationships (Hardcastle 2011:88). The theory was born of an effort to bring people as decision-makers into sociological theory. It was initially thought to be of a concern of equal interest to everyone (Powers 2010:211), but over time those interested in exchange began talking to others, formulating strategies and a new perspective emerged that deserved separate recognition. The theory analyses the exchange relationships as it considers interactions as an independent exchange of positive and negative stimuli which are referred to as 'rewards' and 'costs' (Bender 2011:110), and the theory ultimately suggests that every person is oriented to making choices based on calculations about risks and benefits.

People tend to make benefit-maximising decisions based on their priorities, thinking of the exchange theory in narrow terms; however the researcher believes one needs to think of it in broader terms, in line with corporate social investment, the focus of this study. Sociologists such as Wood (2004) argue that people embark on relationships that are beneficial. Besides, thinking of personal relationships in economic terms, the argument is that people seek to maximise rewards and minimise costs in relationships, and as Wood (2004:192) put it: "we communicate and build relationships to gain rewards and we stay with relationships that are more rewarding than costly and more rewarding than alternatives." Humans base their behaviours on rational calculation designed to maximise individual profit. 
On the other hand, in the context of this study, beneficial relationships between corporations and the communities should occur through exchanging as opposed to economic business. The primary rationale for corporations should be a decision-making with involvement of the heart, employed with passion for its usefulness for an extraordinary partnership with communities (Powers 2010:212). Emphasis is put on the principle of human interaction, which according to McGlynn (2007:11) is the foundation of human interaction, and the desire for gratifications is the key influence on human social choices. This is a symbolic exchange in which interaction is based on exchange of gestures that are packed with meaning. This symbolic approach ultimately validates the significance of the relationships, while heralding the importance of those relationships (Powers 2010:214). However, some scholars have criticised the exchange theory. For them, when the risks outweigh the rewards, people are likely to terminate or abandon that relationship. As the result of an exchange process in which people maximize benefits and minimise costs (Littlejohn \& Foss 2008:27), the theory reveals why exchange takes place as they do, including the reasons people engage in such transactions, why some exchanges succeed and others fail.

Exchange theory has little heuristic value, which means it does not generate new ideas for research in addition to what we know, which is to get satisfaction when exchanging or embarking on relationships (Littlejohn \& Foss 2008:27). People like what is rewarding and dislike what is costly, and naturally satisfied with relationships that meet their expectations. However, they may leave a relationship if a better alternative arises. The principles of the theory are that humans seek gratification through exchange but nothing beyond that. As a result, some scholars have suggested that theory has little heuristic value. The obvious criticism of the theory is that it cannot be tested (Clark \& Mills 1979:12).

\subsection{Resource dependency theory}

Resource dependency theory was developed in the 1970s, at a time when there was a proliferation of important theories dealing with the relationship of organisations to their environments (Smith \& Hitt 2005:434). The theory has been built to address the questions of organisational responses to external pressures and how organisations attempt to manage their environments and attempt to construct them to make them more beneficent. The theory argues that the organisation's primary objective is to ensure the survival of the organisation by reducing uncertainty and ensuring access to required resources (Weissbrich 2009:39). The degree of dependency of an organisation on a resource is influenced by the importance of the resource for the survival of the organisation and the structure of control over it. Therefore, organisations must transact with other elements in their environment to acquire those needed resources (Pfeiffer \& Salancik 2003:10). The theory proposes that actors lacking essential resources to pursue certain goals or conduct their business seek to establish relationships with others in order to obtain the resources they need (Salerno, Jay Yang, Nau \& Chai 2011:71).

Two strategies organisations can apply to deal with the dependency on resources have been identified:

- Organisations can try to bridge the distance to powerful actors by following a cooperation strategy Weissbrich (2009:39), for example, working closely with stakeholders or building personal relationships.

- Community mobilisation is the interaction between knowledge seekers and knowledge providers. Community mobilisation, which depends on the environmental setting, has an impact on overall contributions and is crucial for the public good development strategy (Salerno et al. 2011:71).

Community mobilisation is a valuable source of knowledge that helps development in the communities when knowledge is free and communities view their participation as an investment from which they might obtain future economic returns, such as revenues, and this motivates their engagement. This theory is arguably the most comprehensive in the scope of its approach to companies dealing with power within organisations and how they seek to manage their environment (Davis \& Cobb 2009: 3). The theory offers basic elements while being in support of its account of organisations, that is, environmental relations.

Resource dependency theory is externally focused in the sense that power is held by divisions that are the most important for coping with and solving the critical problems of the organisation that arise from its environment. Units that deal with critical problems and control resources in an organisation are strategic as they manage critical relationships between the firm and its environment to achieve power within the organisation (Mudambi \& Pedersen 2007:9). Managing relationships in a new area has appeared to be crucial as it generates a sense of common wealth and consensus, which results in competitive advantage (Pfeiffer \& Salancik 2003:187). Thus, succeeding in today's environment requires sustaining strategic relationships, and the resource dependency theory can be more relevant to organisation-community relations. In other words, those organisations practice CSI because they will need to sustain strategic relationships with the central constituents, that is, communities. This could give them an edge over other organisations. 
Since CSI activities are directed at managing community relations, this may result in cost and risk reductions (Smith 2002:42). Therefore, building positive community relationships decreases the amount of regulation imposed on the firm. Talking about the resource dependency theory, a sound relationship with the community is crucial to have an advantage over others and succeed in the environment. The concept of community relations is viewed as a function of PR that involves dealing and communicating with the citizens and groups within an organisation's geographic area.

Advocates of the theory state that organisational resource dependencies generate stakeholders and that these organisations influence the environment in order to improve external dependence. However, some of the limits are that organisations react to the environment as they perceive it, but this is affected by the nature of organisational information system (Donaldson 1995:129). For instance, organisations might lobby powerful external organisations such as the government and seek to reassure them that they are already acting in the public interest. Organisational members with specialised competencies or skills can attempt to have critical resources of the organisation defined in a certain way, and hence become its most powerful members.

Resource Dependency critics have seen this as being mechanistic, because the processes are human, with perception and secrecy as important elements, which makes it subjective (Donaldson 1995:130). Another angle is that the theory poses important questions, for instance as to who will control organisations? They have noted the influence of politics, and businesses also play a role within the political system, such as when a corporation lobbies the government with the primary activity being to maximise political influence. They have talked of "dependence- influence theory" (Donaldson 1995:146) as a result of this political interference.

\section{Corporate Social Investment}

Corporate Social Investment (CSI) relates to the activities a company should or can undertake to pursue the goals of society. The philosophical idea of CSI refers to goodwill actions a particular company makes because it believes these are legitimate actions and expectations of citizens of the modern world, as good or responsible action is the one that brings about good consequences or maximises utility (Amaeshi, Osuji \& Nnodim 2008:7). Some business academics, such as Visser, who have shared the philosophical stance, have described four responsibilities that any company has to society namely, economic, legal, ethical and philanthropic, and with which the author argues that corporations should seek to do more than just make a profit (Visser 2011:65). For instance, creating environmental protection or supporting the community's projects that have an impact is a demonstration of the welfare that companies are urged to create (Desjardins \& Mc Call 2005:29).

\subsection{Business ethics and social accountability in the contemporary world}

The reason for embarking on ethical aspects is based upon the number of major scandals in the beginning of the 2000s in the developing world, in particular, and a closer scrutiny of the ethical behaviour in companies. Because of the corporate misdeeds and subsequent scandals at the beginning of the last decade, corporate leaders who were not naturally inclined to be of high ethical character have finally paid attention to the ethical practices (Bibb 2010:45). For this reason, there has been a growth in corporate fear of being exposed for failures of integrity and bad public relations, all of which can affect a company's bottom line. The ethical approach to business is linked to corporate practice and impacts on accountability to a broad group of stakeholders (Solomon 2007:309).

Business ethics and social accountability are to be understood within the context of development of CSR practice, as companies have started to tie accountability into relating practices to transparency (a company's openness about its activities) to the relationships based on trust. Accountability thus becomes a "process that manages power imbalances between the organisation and its stakeholders as well as between a company's various stakeholder groups" (Brenkert 2004: 101). This has led some theorists, such as Brenkert, to develop new tools and methodologies in accountability. He supports the idea of using a barometer as new forms of accountability and also for recovering trust and integrity (Brenkert 2004:101). This will help scandal-prone companies to address various issues that are crucial to stakeholders, as do companies whose corporate traditions already enshrine an acceptable and credible ethos on which the foundations of new forms of accountability could be laid (Brenkert 2004:101).

\section{Research Design and Methodology}

The qualitative research method was employed in this study, found to be suitable for this study because the researcher 
aimed at obtaining an in-depth understanding of CSI, company branding and community relations between the selected institution and the Alexandra community (Babbie \& Mouton 2001:277). According to Shank (2002), it involves the study of subjects in their natural settings whereby the researcher conducts a systematic enquiry into meanings, attempting to interpret and make sense of phenomena and the meanings that people attribute to them. Thus, qualitative research studies a situated world, considering phenomena in their specific macro and micro, social, institutional, political, economic and technological contexts. This qualitative researcher is particularly focused upon understanding process and context of $\mathrm{CSI}$, how the selected financial institution goes about its branding and how the Alexandra community experience the interventions by the institution. To be able to get this understanding use was made of interviews with different stakeholders that elicited their multiple perspectives of the phenomenon under investigation (Denzin \& Lincoln, 2000).

The researchers opted for a phenomenological design for this study. Phenomenology develops an understanding of a subject's reality and how this reality is perceived by the participants in the study. In essence, this approach investigates an individual's or group's perception of reality as they construct it from their perspectives. Thus, the research design involves the specification of procedures for collecting and analysing the data that is necessary to understand CSI, company branding and community relations.

\subsection{Population and sampling}

The population of the study comprised the residents of Alexandra township in the region 5 of Gauteng, which is estimated to contain approximately 350, 000 households (Mahlathini 2010:2). Children under 18 were excluded from the study. From this population a purposive sample comprising three people from the financial institution under investigation, and 19 participants from the community were selected and three members from the institution's management in order to best answer the research questions posed in this study (Saunders, Lewis \& Thornhill 2003:175). The individuals chosen had been staying in Alexandra before the start of the project and therefore were able to respond to research questions.

\subsection{Data collection method}

In the first part of the study, which was aimed at identifying the organisational perspective on CSI and the financial institution's community relations in Alexandra, three in-depth informant interviews were conducted with representatives of the institution. The researchers conducted three focus groups with the communities of Alexandra and three in-depth interviews with the management of the financial institution, as this was the primary data gathering strategy. Firstly, the advantage was that focus groups are more than just the researcher asking questions to informants in a group of setting (Hatch 2002:132). They give the researchers a unique character of interaction that takes place among participants in the group to generate data from several people. The goal was to create conversation with the participants by exploring the topic in depth. The major advantage was the capacity to produce concentrated data on the topic of interest (Morgan 1997:13). This enabled the process to be interactive as instead of the researchers monopolising the debate by asking questions, people were encouraged to discuss freely and talk to one another asking questions, exchanging ideas and commenting on other's opinions and experiences. The researchers then attempted to explore people's knowledge and experiences and examined not only what they thought about the questions being posed to them but also why they thought that way. In terms of monitoring, and in order to make the discussion as interactive as possible, the researchers gave space to participants to comment on other individual's views as contradictions could only enrich the focus group talks and give the researcher additional perspectives.

\subsection{Data analysis}

After the collection and recording, data analysis was carried out, which is the amount of data gathered so that capsule statements about it can be provided (Hardy \& Bryman 2009:4). From the various analytical methods, the researchers opted for the constant comparative method, as suggested by Merriam (1998:178-87). In this way, a voluminous amount of information was reduced to certain categories then interpreted using a schema. Three levels of analysis were followed in this study:

1. Data was compressed and linked together with the meaning the researchers had derived from studying the phenomenon.

2. The second level of analysis involved constructing categories that capture recurring patterns. Categories were 
constructed, informed by the researchers' knowledge and the meanings arising from the informants.

3. The third level of analysis involved making inferences. In this phase, integration and refinement of categories were carried out.

For this qualitative work, additional features were identified and helped the researchers to analyse data. These were open coding, axial coding, selective coding and memo-ing (Strauss \& Corbin 1994:9). These four features are interrelated although they have their own logic, enabling the researchers to understand and describe the situation being investigated (Hammersley 1992:4). For open coding, we identified, labelled and categorised variables in line with the study. After open coding, the researchers put data together in new ways that enabled a form of coding paradigm to be used, which explained relationships between categories in the axial coding (Kelle 2005; Strauss \& Corbin 1990:96). During this phase, we made explicit the relationships between categories in order to understand how they related. Lastly, the researchers selected and identified the core categories and developed them. Those categories were integrated.

We collected a substantial amount of written text from focus groups and analysis of information that followed the same principles. Ordering of data was conducted by raw field notes being transformed into a well-organised set of notes. This reflected what was discussed by the participants. The text was organised under headings such as 'developmental approach' that were in line with the research topic. We displayed summaries of data in a way that interpretation became easy, by listing data that belonged together. Data displays, according to Adler and Clark (2011:463), are the visual images that present information systematically and in a way that allows the researcher to interpret. Then, the researchers drew conclusions. As variables went together because of their relationship, they were associated and conclusions were drawn.

\section{Methods of Achieving Trustworthiness}

Trustworthiness is an essential criterion of qualitative research and therefore it was adhered to. Babbie and Mouton (2001:276) have identified transferability, credibility, dependability, and conformability as criteria of qualitative research to test trustworthiness. Transferability means that the findings can be transferred to other contexts or with other respondents (Holloway \& Wheeler 2002:255). Transferability refers to the objectivity of the findings of the research investigation (Babbie \& Mouton 2001:276). The dependability is "a description of a research design allowing researchers to repeat the study" (Babbie \& Mouton 2001:278), whilst credibility is an evaluation of whether or not the research findings represent a credible conceptual interpretation of the data drawn from the participants' original data (Lincoln \& Guba 1985: 296). Conformability is a measure of how well the inquiry's findings are supported by the data collected (Lincoln \& Guba 1985: 297). The findings of the research should focus on the inquiry and not the bias of the researcher (Babbie \& Mouton 2001:276), and refer to the degree to which the results could be confirmed or corroborated by others. There are a number of strategies for enhancing conformability.

\section{Ethical Considerations}

The researchers recognised the relevant aspects of ethical considerations prescribed at the Vaal University of Technology, preserving anonymity of the organisation being researched by referring to it in the dissertation as 'the financial institution'. In the quest for new knowledge and understanding of the academic environment, the researcher took into account responsibility and accountability that go with research. This implied applying methods that are morally and ethically acceptable. We ensured privacy of participants with regards to protecting their anonymity, and this arrangement was made from the start of the discussion with participants. We also ensured that information obtained from the participants was and shall be protected and therefore not be made public. Cohen and Manion (1994:367) suggest this second method is to ensure a participants' right to privacy, and despite the researcher knowing who supplied information he or she would not share it for ethical reasons. We also made sure the study is repeatable and that any other qualitative researcher should be able to achieve similar results under similar circumstances. The individuals chosen were not being forced to take part in the research against their will. For ethical, legal and moral concerns the researchers treated respondents with courtesy and civility, irrespective of their status, be it the unemployed residents or the institution management.

\section{Discussion of Findings}

The data was analysed with regards to the conceptual framework, divided and discussed according to the research's 
units of analysis: corporate social investment (CSI) and brand image, within the financial institution and the Alexandra communities.

\subsection{Corporate social investment and community relations}

The term CSI was not used by the researchers when conducting focus groups with the communities as it was assumed they might not understand what it entailed, but rather referred to the term CSI as 'projects and programmes'. While the communities all acknowledged the presence of projects led by the financial institution as indicated, they all regretted lack of consultation and collaboration upfront as for them being the beneficiaries, therefore stakeholders imply they should have a say. This is very much in line with concept of relationships (Grunig \& Huang 2001), especially the trust and satisfaction dimensions.

The concepts of consultation, collaboration and partnership were frequently used by the respondents, who agreed that these should be applied from the earliest stages of the project. The community members referred to this as a 'working culture, which, according to them, was conducive to successful collaboration. Collaboration and partnership both involve participants using a number of skills and approaches as two parties join towards achieving a common purpose. Collaboration tends to transcend individual projects and focus on problems that require the pooling of ideas and skills to address issues. The respondents observed that the scope of the project could expand beyond education into other areas, such as local talent identification and development or promoting arts, if they were consulted. The respondents were also critical of the monitoring and evaluation process that takes place at the centre at the end of the year, as it is too focused on short-term deliverables as opposed to long-term outcomes. Furthermore, focus on a long-term impact would provide an accurate reflection of the project's value and success.

The members of the community were also wary of real reasons the big businesses in general embarked on community projects. The participants believed that corporations gained by assisting the communities, however, these perceived gains differed from those suggested by CSI literature, such as: improving organisational financial performance, building corporate reputation, or tapping into the community knowledge (Salerno et al. 2011:71). The benefits to the company as viewed by the focus group respondents were more centred on short impact gains, for example obtaining labour or spreading information about new products to other community members. In terms of community relations, this highlights the issue of the distrust towards big corporate organisations among community members. It can be deduced from the responses that out of the three dimension of trust: integrity, dependability and competence, as identified by Scott (2009: 263), integrity and competence were most under the scrutiny of the respondents. The third dimension, dependability, was almost taken for granted and the respondents did not express a possibility that the financial institution might stop financing the project in the near future, perhaps because it had been involved in the project for a number of years.

From the financial institution perspective, the three interviewees agreed that the projects taking place were part and parcel of their CSI initiatives, a developmental approach pursued by corporate South Africa that aimed to uplift lives of the citizens. Such a statement may indicate that the involvement of big business in CSI in South Africa was to a large extent institutionalised. Furthermore, respondents believed that establishing good relations referred to as 'community relations' with the communities was crucial if the projects were to have any impact. In general, the managers had a much more positive view of their company's CSI involvement than the community. In contrast, the focus groups highlighted numerous shortcomings of the project from the community perspective, such as including the lack of consultation and fairly narrow scope of the project. This finding is in line with research by Skinner and von Essen (2008: 241), indicating that in South Africa the majority of companies that ran CSI programmes did not engage the communities in regular consultations or evolution of these programmes. In the case of the financial institution, it was left to the intermediaries, government.

\subsection{Brand Image}

The financial institution's brand image is well established as it is a well-known financial institution, existing for a number of years and well-supported by marketing communications. The community members referred to the ever presence of the advertising material displayed by the organisation in the community centre and during various activities. They had a perception of the financial institution as 'good', but this view does not translate into existing community relationships. This may indicate that the community members separated the organisation's CSI involvement from their business activities. On the other hand, the management strongly cares about a positive brand image within the communities, as indicated in 
the many responses which recognised that embarking on a social cause is one thing but the main aim is to have more exposure and visibility among the communities. Brand image is a highly valued aspect, recognised by the financial institution in the community's social service delivery. All management respondents have admitted striving to manage image and reputation, seen as 'mechanisms of social control' that enable the communities to be committed to them. However, it is not clear from the responses of the focus group participants whether the financial institution's involvement in the CSI had any direct impact on their decision to use the services of the financial institution in question. As stated above, the institution was a well-established and well-known financial service provider in South Africa, and most of the respondents were familiar with it before the Alexandra project began.

\section{Conclusion}

The major findings revealed that corporate social investment (CSI) did take place in Alexandra and the communities witnessed this through the projects, which from their perceptions ultimately contributed to a positive brand image. However, lack of consultation and collaboration from the institution management unfortunately did not contribute to establishing good community relationships with the communities, albeit valued by the organisation. It was found that the community centre was seen as a third party or task team, because of a political driven agenda, and was not seen as sufficiently reliable by the communities and should therefore be held accountable by the organisation during the monitoring and evaluation. This suggests implementation of the projects should be re-examined by the organisation if the relationships between them and the communities are to be friendlier.

In terms of brand image, the findings revealed that the financial institution was well known among the communities, however, it is not clear to what extent its involvement in a community project in Alexandra affected its corporate brand image. As a major financial institution, emphasis was placed on making sure the group was visible, but a chasm existed between image portrayed and the feelings expressed by the intended: "The organisation is good but the people are not visible" as respondents have expressed. This indicates that the community expected much more direct and interactive involvement from the representatives of the financial institution in question. This is evidence that although the financial institution financed the project it did not have direct involvement in running it. This resulted in a perceived separation of the financial institution's brand image as service provider and its image in terms of the community relations.

\section{Recommendations}

In line with the findings of this study, the following recommendations are made. As the corporate sector in South Africa is actively taking part in the development process through Corporate Social Investment (CSI) and knowing organisations do not hold the resources to address the problem single-headedly, broader stakeholders seen as potential partners need to be involved in the party in order for the projects to have more effect and impact. Therefore, it is important to have closer cooperation with the NGOs managing or assisting the financial institution in managing its CSI projects, as with the one in Alexandra township. It is recommended that the financial institution engage with local communities and not limit their decisions based on briefings coming from the community centre, so as to have a clear picture and a shared vision with the larger community. It is important for the financial institution to directly involve the communities through consultation, collaboration and partnership if it is to balance the long-term impact against short-term outcomes during the monitoring and evaluation process.

\section{References}

Adler, E.S. \& Clark, R. (2011). An invitation to social research: How it's done. (4th ed). Belmont, CA.

Amaeshi, K., Osuji, O. \& Nnodim, P. (2008). 'Corporate social responsibility in supply chains of global brands: A boundaryless responsibility? Clarifications, exceptions and implications'. Journal of Business Ethics, 81: 223-234.

Babbie, E. \& Mouton, J. (2001). The practice of social research. Cape Town: Oxford University Press.

Bender, M. (2011). Social exchange theory. California State University.

Bibb, S. (2010). The right thing: an everyday guide to ethics in business. United Kingdom: The Atrium West Sussex.

Brenkert, G.G. (2004). Corporate integrity and accountability. London: Sage.

Clark, M.S. \& Mills, J (1979). Social exchange theory. An interdisciplinary review. Journal of Management, 37:12-24.

Cohen, L. \& Manion, L. (1994). Research methods in education. London: Routledge.

Dahlen, M., Lange, F \& Smith, T. (2010). Marketing and communications: A brand narrative approach. West Sussex: Wiley \& Sons.

Davis, G.F. \& Cobb, J.A. (2009). Resource dependency theory. Past and future. University of Michigan.

Denzin, N.K. \& Lincoln, Y.S.(2000). The discipline and practice of qualitative research. In N.K. Denzin \& Y.S. Lincoln (eds). Handbook of 
Qualitative Research. (2nd ed). Thousand Oaks: Sage Publications. pp. 1-28.

Desatnik, L. (2000). Corporate Volunteering is Good Business. Cincinnati Business Journal, [Online] Available: www.reference.com (September 1, 2000)

Desjardins, J.R \& Mc Call, J.J. (2005). Contemporary Issues in Business Ethics. (5 $5^{\text {th }}$ ed). USA: Wadsworth.

Donaldson, L. (1995). The contingency theory of organisations. Sydney: Sage Publications.

Georges, E.P. (2005). The administrator's guide to school-community relations. (2nd ed). New York: Larchmont.

Grunig, J.E. \& Huang, Y. 2000. From organisational effectiveness to relationship indicators: antecedents of relationships, public relations strategies and relationship outcomes. In Ledingham, J.A, \& Bruning, S.D. Public relations as relationship management. Mahwah, New Jersey: Lawrence Erlabuam. pp. 23-54.

Hardcastle, D.A. (2011). Community practice: Theories and skills for social workers. Oxford: University Press.

Hardy, M.A. \& Bryman, A. (2009). Handbook of data analysis. United Kingdom: Amazon.

Hatch, J.A. (2002). Doing qualitative research in education settings. New York: Albany Press.

Healey, M. (2008). What is branding: essential design handbooks. United Kingdom: Hove.

Hinson, R.E. \& Ndhlovu, T.P. (2011). Conceptualising corporate social responsibility (CSR) and corporate social investment (CSI): The South African context. Social Responsibility Journal, 7:332-346.

Holloway, T. \& Wheeler, R. (2002). The management of a student project. London: Gower Publishing Company.

James, E. (2002). Relationships with communities: New approaches by corporate executives. (2nd ed). Boston: Publishing Company.

L'etang, J. (2008). Public relations concepts practice and critique. London: Sage.

Littlejohn, S. W. \& Foss, K.A. (2008). Encyclopaedia of communication theory. California: Sage Publications.

Mahlathini, S. (2010). Report on the interactive planning workshop for Alexandra, Johannesburg, 27 September 2010. [Online] Available: < http://www.alexandra.Gauteng.co.za>. (December 13, 2010)

Merriam, S.B. (1998). The constant comparative method: A guide to design and implementation. San Francisco: Jossey-Bass.

Morgan, D.L. (1997). Focus groups as qualitative research. London. Sage Publications.

Mudambi, R. \& Petersen, T. (2007). Agency theory and resource dependency theory. Palgave: Macmillan.

Pfeiffer, J. \& Salancik, G. (2003). The external control of organisations: a resource dependency perspective. Stanford: University Press.

Polonski, M \& Jevons, C. (2009). Global branding and strategic CSR: an overview of three types of complexity, International Marketing Review, 26:327-347.

Powers, D. (2010). Social exchange theory. New York: Premium Publishers.

Rashid, Z. \& Ibrahim, S. (2002). Executive and management attitudes towards corporate social responsibility in Malaysia. Corporate Governance, 2:10-16.

Salerno, J., Jay Yang, S \&Nau, D. (2011). Social Computing Behaviour: cultural modelling and prediction. (4th ed). London: Vita

Sandra, M. (1996). Living in community. (6th ed). New York: Wadsworth.

Saunders, M., Lewis, P. \& Thormhill, A. (2003). Research methods for business studies. Harlow: Prentice-Hall.

Scott, J. (2009). Relationship measures applied to practice. In Toth, E.L. The future of excellence in public relations and communication management. New York: Routledge. pp. 263-274.

Shank, G.D. (2002). Qualitative research: A personal skills approach. Upper

Saddle River, New Jersey: Pearson Education.

Skinner, C. \& Mersham, G. (2008). Corporate social responsibility in South Africa: emerging trends. Society and Business Review, 3:239-255.

Smith, K.G. \& Hitt, M.A. (Eds). (2005). The resource dependency theory: Past and future. London. Rindova

Soderberg, N.R. (1986). Public relations for the entrepreneur and the growing business. London: Probus.

Solomon, J. (2007). Corporate governance and accountability. West Sussex: The Atrium, Chichester.

Strauss, A.L \& Corbin, J.M (1994).Grounded theory methodology: An overview. In: Denzin, N. K. \& Lincoln, Y.S. (eds). Handbook of qualitative research. London: Sage Publications.

Tull, D.S. \& Hawkins, D.I. (1987). Marketing research: measurement and methods. (4 $\left.{ }^{\text {th }} \mathrm{ed}\right)$. New York: Macmillan Publishing Company. Visser, W. (2011). The age of responsibility: CSR 2.0 and the New DNA of business. West Sussex: John Willey.

Weissbrick, B. (2009). The marketing sales finance triangle. Cambridge: University Press.

William, B., Werther, Jr. \& Chandler, D. (2011). Strategic corporate social responsibility: stakeholders in a global environment. London: Sage.

Wood, J.T. (2004). Social relations and exchanges. New York: Raschick \& Ingersoll-Dayton. 